\title{
Inhibitory effect of Gardenblue blueberry (Vaccinium ashei Reade) anthocyanin extracts on lipopolysaccharide-stimulated inflammatory response in RAW 264.7 cells $^{*}$
}

\author{
Wei XU ${ }^{\S 1,3}$, Qing ZHOU ${ }^{\S 2}$, Yong YAO ${ }^{1}$, Xing $\mathrm{LI}^{1}$, Jiu-liang ZHANG ${ }^{\dagger 1,4}$, Guan-hua SU ${ }^{5}$, Ai-ping DENG ${ }^{2}$ \\ ( ${ }^{1}$ College of Food Science and Technology, Huazhong Agricultural University, Wuhan 430070, China) \\ ('Department of Pharmacy, Wuhan City Central Hospital, Tongji Medical College, \\ Huazhong University of Science and Technology, Wuhan 430014, China) \\ $\left({ }^{3}\right.$ Research Center for Food Safety and Nutrition, Key Lab of Urban Agriculture (South), Bor S. Luh Food Safety Research Center, \\ School of Agriculture \& Biology, Shanghai Jiao Tong University, Shanghai 200240, China) \\ $\left({ }^{4}\right.$ Key Laboratory of Environment Correlative Dietology (Huazhong Agricultural University), Ministry of Education, Wuhan 430070, China) \\ ( ${ }^{5}$ Department of Cardiology, Union Hospital, Tongji Medical College, Huazhong University of Science and Technology, Wuhan 430022, China) \\ †E-mail: zjl_ljz@mail.hzau.edu.cn \\ Received Sept. 4, 2015; Revision accepted Dec. 18, 2015; Crosschecked May 12, 2016
}

\begin{abstract}
Blueberries are a rich source of anthocyanins, which are associated with health benefits contributing to a reduced risk for many diseases. The present study identified the functional Gardenblue blueberry (Vaccinium ashei Reade) anthocyanin extracts (GBBAEs) and evaluated their capacity and underlying mechanisms in protecting murine RAW 264.7 cells from lipopolysaccharide (LPS)-stimulated inflammation in vitro. Enzyme-linked immunosorbent assay (ELISA) kit results showed that GBBAEs significantly inhibited the production of nitric oxide (NO), prostaglandin $E_{2}$ $\left(\mathrm{PGE}_{2}\right.$ ), interleukin-6 (IL-6), IL-1 $\beta$, and interferon- $\gamma$ (INF- $\gamma$ ). Real-time polymerase chain reaction (PCR) analysis indicated that the mRNA expression levels of IL-6, IL-1 $\beta$, tumor necrosis factor- $\alpha$ (TNF- $\alpha$ ), monocyte chemoattractant protein-1 (MCP-1), and cyclooxygenase 2 (COX-2) were suppressed in LPS-stimulated RAW 264.7 cells. Additionally, Western blot analysis was used to evaluate the relative protein expression levels of COX-2 and nuclear factor-kB p65 (NF-kBp65). All these results suggested the potential use of GBBAEs as a functional food for the treatment of inflammatory diseases.
\end{abstract}

Key words: Gardenblue blueberry (Vaccinium ashei Reade) anthocyanin extracts (GBBAEs), Anti-inflammatory, RAW 264.7, Cyclooxygenase 2 (COX-2), Nuclear factor-kB p65 (NF-kBp65)

CLC number: O629.9

\section{Introduction}

Inflammation response is a complex and crucial

${ }^{\ddagger}$ Corresponding author

${ }^{\S}$ The two authors contributed equally to this work

* Project supported by the Fundamental Research Funds for the Central Universities of China (No. 2013PY095), the Clinical Research Project of Health and Family Planning Commission of Wuhan Municipality (No. WX13A05), the Research Project of Wuhan City Central Hospital (No. YQ15A04), and the Grant from Key Laboratory of Biological Targeted Therapy of Hubei Province of China (No. 02.03.2014-10) (1D) ORCID: Jiu-liang ZHANG, http://orcid.org/0000-0002-1745-846X

(C) Zhejiang University and Springer-Verlag Berlin Heidelberg 2016 process mediated by both several inflammatory cytokines (interferon- $\gamma$ (INF- $\gamma$ ), interleukin-1 $\beta$ (IL-1 $\beta$ ), and IL-6) and related inflammatory mediators such as prostaglandin $\mathrm{E}_{2}\left(\mathrm{PGE}_{2}\right)$ and nitric oxide $(\mathrm{NO})$, which are produced by cyclooxygenase $2(\mathrm{COX}-2)$ and inducible nitric oxide synthase (iNOS), respectively (Kim et al., 2013; Cheng et al., 2014). COX-2 and 
nuclear factor- $\mathrm{kB}(\mathrm{NF}-\mathrm{\kappa B})$ activations are well-known biological markers for inflammatory responses. Inflammatory cells such as monocytes and macrophages can produce a large repertoire of cytokines and participate in the pathogenesis of diseases (Yan et al., 2013). So it is valuable to recognize antiinflammatory mechanisms in order to find treatments and adjuvant treatments of many diseases.

Lipopolysaccharide (LPS) is an endotoxin, an integral outer membrane component used to assess Gram-negative bacteria, and triggers the most potent microbial initiators of inflammatory response, including septic shock, fever, and microbial invasion (Dobrovolskaia and Vogel, 2002). LPS induces $\mathrm{NF}-\kappa \mathrm{B}$ activation via several signal transduction pathways, all of which inhibit the phosphorylation of

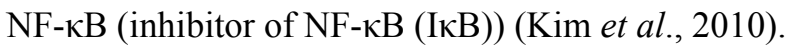
The LPS-stimulated RAW 264.7 cell model is one of the typical virus-induced inflammation models in vitro.

Blueberries are rich in a variety of functional components, such as flavone, organic acid, anthocyanin, superoxide dismutase (SOD), polysaccharides, and mineral elements, contributing to the treatments for many diseases (Almeida et al., 2007). Although Gardenblue blueberry (Vaccinium ashei Reade) anthocyanin extracts (GBBAEs) are best recognized for their antioxidant properties with their mechanisms being studied thoroughly (Prior et al., 1998; Sun et al., 2012; Li et al., 2013), recent studies indicated that it is the anti-inflammatory aspect that is responsible for treating cancer and cardiovascular diseases (Johnson et al., 2013; Esposito et al., 2014). Varieties of polysaccharides, glycosides, and alkaloids have proven to have the best anti-inflammatory activity (Hsu et al., 2013; Wang L. et al., 2014). Also, there are studies on the anti-inflammatory effect of blueberries (Cheng et al., 2014; Esposito et al., 2014), but the detailed capacity and underlying mechanisms in GBBAEs are still to be elucidated. There were only a few reports on the verification of the anti-inflammatory capacity and mechanisms of the RAW 264.7 cell model. Also, the mechanism of the NF- $\mathrm{kB}$ pathway in GBBAEs was evaluated for the first time. Therefore, the objectives of the current study were: (1) to evaluate the inhibitory effect of inflammatory cytokines (NO, $\mathrm{PGE}_{2}$, IL-6, IL-1 $\beta$, and INF- $\gamma$ ) release; (2) to evaluate the mRNA gene expression levels of the IL- 6 , IL- $1 \beta$, tumor ne- crosis factor- $\alpha$ (TNF- $\alpha$ ), monocyte chemoattractant protein-1 (MCP-1), and COX-2 in LPS-stimulated RAW 264.7 cells; (3) to evaluate the relative protein expressions of COX-2 and NF-kBp65; (4) to determine the anti-inflammatory mechanism of GBBAEs.

\section{Materials and methods}

\subsection{Materials and chemicals}

The blueberry we used is Gardenblue blueberry. They are obtained from Hubei Cowherd Blueberry Technology Co., Ltd., whose planting base was located in Huangpi District, Hubei Province, China. The cell culture medium (GNM-12800), trypsase (GMN-15400), and penicillin-streptomycin were purchased from Jinuo Biotechnology Co., Ltd. (Hangzhou, China). Fetal bovine serum (FBS) was purchased from Hangzhou Tianhang Biotechnology Co., Ltd. (Hangzhou, China) and the Dulbecco's modified Eagle's medium (DMEM) was purchased from Hyclone (USA). 3-(4,5-Dimethy-2-lthiazolyl)-2,5-diphenyl-2Htetrazolium bromide (MTT) and LPS were obtained from Sigma (USA). Enzyme-linked immunosorbent assay (ELISA) kits for mouse $\mathrm{PGE}_{2}, \mathrm{IL}-6, \mathrm{IL}-1 \beta$, and INF- $\gamma$ were purchased from Nanjing Jiancheng Bioengineering Institute (Nanjing, China). TRIzol reagent was obtained from Invitrogen Life Technologies (Germany) and the RevertAid First Strand cDNA Synthesis Kit was obtained from Thermo (Germany). FastStart Universal SYBR Green Master (Rox) was purchased from Roche (Switzerland). All other reagents were of analytical grade.

\subsection{GBBAEs' preparation and high-performance liquid chromatography-mass spectrometry/mass spectrometry analysis}

The GBBAEs were obtained from fresh-freezed Gardenblue blueberry. Briefly, the $50 \mathrm{~g}$ of freshfreezed Gardenblue blueberry was weighed out and placed in a capacity tube, followed by the addition of $60 \%$ alcohol $(15 \mathrm{ml} / \mathrm{g})$ as extracting solvent into the sample tube. Then $0.1 \mathrm{~mol} / \mathrm{L} \mathrm{HCl}$ was added to adjust the $\mathrm{pH}$ to 3. After being mixed briefly, the sample tubes were placed on magnetic stirrers at $40^{\circ} \mathrm{C}$ for $2 \mathrm{~h}$. The extraction process on magnetic stirrers was repeated twice. Then $5 \mathrm{mg} / \mathrm{ml}$ aqueous solution of the 
crude extracts was loaded onto an AB-8 resin (weak polarity macroporous resin, $0.3-1.25 \mathrm{~mm}$ particle size, Nankai Hecheng Science \& Technology Co., Tianjin, China) column $(25 \mathrm{~mm} \times 100 \mathrm{~mm})$. After that, the column was water-washed. Finally the fraction eluted with $60 \%$ ethanol was collected. After the eluant was evaporated and freeze-dried, GBBAEs were obtained and then stored at $-20{ }^{\circ} \mathrm{C}$ in sealed aluminum bags for future experiment. $\mathrm{pH}$-differential method and high-performance liquid chromatography (HPLC) with a C18 column were applied to the total anthocyanin content using cyanidin 3 -glucoside as adequate standards to calculate the equivalent per $100 \mathrm{~g}$ in the GBBAEs (Zhang et al., 2015).

The individual anthocyanins were separated by an Agilent 1100 HPLC equipped with a diode array detector connected to an Agilent 6300 mass spectrometer (Agilent Technologies Inc., Santa Clara, CA, USA), and a $5 \mu \mathrm{m} \times 250 \mathrm{~mm} \times 4.6 \mathrm{~mm}$ TSKgel C18 column (Tosoh Corp., Tokyo, Japan). The temperature of the column was set at $30{ }^{\circ} \mathrm{C}$ during the HPLC analysis. The injection volume of the solution $(1 \mathrm{mg} / \mathrm{ml})$ of GBBAEs was $10 \mu \mathrm{l}$. Solvent A was $5 \%$ $(\mathrm{v} / \mathrm{v})$ formic acid in water, and solvent B was $100 \%$ methanol. The solvent gradient was: 0 to $5 \mathrm{~min}, 100 \%$ to $75 \% \mathrm{~A} ; 5$ to $25 \mathrm{~min}, 75 \%$ to $60 \% \mathrm{~A} ; 25$ to $40 \mathrm{~min}$, $60 \%$ to $50 \% \mathrm{~A} ; 40$ to $42 \mathrm{~min}, 50 \%$ to $55 \% \mathrm{~A} ; 42$ to $44 \mathrm{~min}, 55 \%$ to $40 \% \mathrm{~A} ; 44$ to $46 \mathrm{~min}, 40 \%$ to $35 \% \mathrm{~A}$; 46 to $52 \mathrm{~min}, 35 \%$ to $30 \% \mathrm{~A}$. The individual anthocyanins were obtained by HPLC-diode array detection (DAD) at $525 \mathrm{~nm}$. For mass spectrometry (MS) acquisition, mass spectra in the $\mathrm{m} / \mathrm{z}$ range of 100 1000 were obtained by electrospray ionization in positive-ion mode. For MS acquisition, a capillary voltage of $4.5 \mathrm{kV}$, a pressure of nebulizing nitrogen of 35 psi ( $1 \mathrm{psi}=6.895 \mathrm{kPa})$, a capillary temperature of $325^{\circ} \mathrm{C}$, and dry gas flow at $10 \mathrm{~L} / \mathrm{min}$ were applied. The compounds were presented by the relative contents by comparing the peak area of HPLC-MS/MS.

\subsection{Cell culture}

Culture RAW 264.7 cell lines were gifts from the College of Animal Science and Technology, Huazhong Agricultural University (Wuhan, China). RAW 264.7 cells were cultured in DMEM supplemented with $10 \%$ FBS and $1 \%$ penicillin-streptomycin at $37{ }^{\circ} \mathrm{C}$ in a $5 \% \mathrm{CO}_{2}$ humid atmosphere (Thermo, Germany), until they reached $90 \%$ confluence.

\subsection{Cell viability assay}

The cytotoxicity of GBBAEs against the RAW 264.7 cells was assessed by an MTT assay (Lopes et al., 2012). RAW 264.7 cells were plated into 96well plates in triplicate at a density of $2 \times 10^{4}$ cells/well and incubated for $24 \mathrm{~h}$. After $24 \mathrm{~h}$, the culture medium was replaced by $200 \mu \mathrm{l}$ serial dilutions of GBBAEs $(50,100,200,400,800,1200,1600 \mu \mathrm{g} / \mathrm{ml}$, each dilution owns six duplicate wells) and further incubated for 24,48 , and $72 \mathrm{~h}$ at $37^{\circ} \mathrm{C}$ in a $5 \% \mathrm{CO}_{2}$ humid atmosphere. Sterile filtered MTT stock solution $(5 \mathrm{mg} / \mathrm{ml})$ was diluted to $0.5 \mathrm{mg} / \mathrm{ml}$ by phosphatebuffered saline (PBS, $\mathrm{pH}=7.4$ ) and then was added to each well to reach the reaction volume of $200 \mu \mathrm{l}$. After 4-h incubation, the supernatant medium was removed, and dimethyl sulfoxide (DMSO) $(150 \mu \mathrm{l})$ was added to each well to dissolve the formazan crystals. Then the plates were read immediately at $490 \mathrm{~nm}$ on a microplate reader (BioTek, Vermont, USA). The cell viability was calculated by the following formula: cell viability $=\left(A_{\mathrm{e}}-A_{\mathrm{bc}}\right) /\left(A_{\mathrm{c}}-A_{\mathrm{bc}}\right) \times 100 \%$, where $A_{\mathrm{e}}, A_{\mathrm{c}}$, and $A_{\mathrm{bc}}$ are the mean absorbances of experiment, control, and blank control, respectively.

\subsection{NO production assay}

The NO levels in the cultured media, which reflect NO activity, were determined by the Griess reaction (Hsu et al., 2013). RAW 264.7 cells were plated into 24 -well plates at a density of $1 \times 10^{6}$ cells/well and incubated for $24 \mathrm{~h}$. After the culture period, cells were exposed to different concentrations of GBBAEs $(0,400,800,1200,1600 \mu \mathrm{g} / \mathrm{ml}$, diluted by GNM12800 culture medium, each dilution owns three duplicate wells) for $1 \mathrm{~h}$. After $1 \mathrm{~h}, 20 \mu \mathrm{l}$ LPS $(50 \mu \mathrm{g} / \mathrm{ml})$ was added to each well to reach the final concentration of $1 \mu \mathrm{g} / \mathrm{ml}$ and cells were maintained in culture for $24 \mathrm{~h}$ under the same conditions. An assay without LPS was prepared. After incubation, $100 \mu \mathrm{l}$ of the cell culture supernatant was mixed with an equal volume of Griess reagent $(0.1 \%(1 \mathrm{~g} / \mathrm{L}) \mathrm{N}$-(1-naphthyl) ethylenediamine dihydrochloride and $1 \%(0.01 \mathrm{~g} / \mathrm{ml})$ sulfanilamide in $5 \%(\mathrm{v} / \mathrm{v})$ phosphoric acid). The samples were incubated at room temperature for $15 \mathrm{~min}$, and then the absorbance was measured at $540 \mathrm{~nm}$ using a microplate reader. The quantity of NO was determined from a sodium nitrite standard curve. Also, the supernatant was removed and stored at $-20{ }^{\circ} \mathrm{C}$ for later analysis. 


\subsection{Determination of $\mathrm{PGE}_{2}$ production}

The GBBAEs were diluted with DMEM prior to treatment. Cells were treated for $24 \mathrm{~h}$ with LPS $(1 \mu \mathrm{g} / \mathrm{ml})$ to permit cytokine production. The $\mathrm{PGE}_{2}$ concentration in the culture medium was quantified using a competitive enzyme immunoassay kit (R\&D Systems, USA) in accordance with the manufacturer's instructions. The production of $\mathrm{PGE}_{2}$ was measured relative to that observed after control treatment.

\subsection{Measurement of proinflammatory cytokine (INF- $\gamma$, IL-1及, and IL-6) production}

The GBBAEs were diluted with DMEM prior to treatment. The inhibitory effects of GBBAEs on the production of proinflammatory cytokines (INF- $\gamma$, IL-1 $\beta$, and IL-6) from LPS-treated RAW 264.7 cells were determined as described previously. The supernatants were subsequently employed for the proinflammatory cytokine assays using a mouse ELISA kit (R\&D Systems, USA).

\subsection{Real-time PCR analysis}

The total RNA was extracted from RAW 264.7 cells and collected after GBBAEs and LPS treatments using TRIzol reagent (Invitrogen, USA) according to the manufacturer's instructions. Two microgram of total RNA was added to the tubes with $1 \mu$ of oligo (dT) 15 primers and added deionized water without RNase to $20 \mu \mathrm{l}$. These tubes were kept at $70{ }^{\circ} \mathrm{C}$ for 5 min and cooled rapidly. Then $4 \mu$ of $5 \times$ buffer, $2 \mu \mathrm{l}$ of $10 \mathrm{mmol} / \mathrm{L} \mathrm{dNTPs}, 1 \mu \mathrm{l}$ of RNA inhibitor, and $1 \mu \mathrm{l}$ of inverse transcriptase in each were added. Then the tubes were kept at $42{ }^{\circ} \mathrm{C}$ for $30 \mathrm{~min}$, and the reactions were stopped by heating the RNA solution at $80{ }^{\circ} \mathrm{C}$ for 5 min. Complementary DNA (cDNA) was generated using the RevertAid First Strand cDNA Synthesis Kit (Thermo, Germany). cDNA was used as a template to amplify for real-time polymerase chain reaction (RT-PCR) in triplicates with FastStart Universal SYBR Green Master (Rox) and gene-specific primers. PCR analysis was performed on an ABI (Step-One-Plus) Real-Time PCR system. PCR primers used in this study were as follows: M-GAPDH-S, 5'-AGG AGC GAG ACC CCA CTA ACA-3'; M-GAPDH-A, 5'-AGG GGG GCT AAG CAG TTG GT-3'; M-MCP-1-S, 5'-AGG TGT CCC AAA GAA GCT GTA GT-3'; M-MCP-1-A, 5'-TTT GGT TCC GAT CCA GGT TTT-3'; M-IL-6-S, 5'-GAA ATG
ATG GAT GCT ACC AAA CTG-3'; M-IL-6-A, 5'-GAC TCT GGC TTT GTC TTT CTT GTT-3'; M-TNF- $\alpha-S$, 5'-TAC TGA ACT TCG GGG TGA TCG-3'; M-TNF- $\alpha-A, 5$ '-GGG TCT GGG CCA TAG AAC TGA-3'; M-IL-1 $\beta$-S, 5'-TCA AAT CTC GCA GCA GCA CAT C-3'; M-IL-1 $\beta$-A, 5'-CGT CAC ACA CCA GCA GGT TAT C-3'; M-COX-2-S, 5'-GAA GTT GAT AAC CGA GTC GTT C-3'; M-COX-2-A, 5'-CCA TAG AAT AAC CCT GGT CG-3'.

The PCR amplifications were performed with initial heat denaturation at $95{ }^{\circ} \mathrm{C}$ for $10 \mathrm{~min}$ and the PCR cycles were repeated 40 times under the following conditions: denaturation at $95{ }^{\circ} \mathrm{C}$ for $15 \mathrm{~s}$, annealing at $60{ }^{\circ} \mathrm{C}$ for $60 \mathrm{~s}$, and the last extension at $60{ }^{\circ} \mathrm{C}$ for $5 \mathrm{~min}$. The dissociation curve was completed with one cycle from 75 to $95{ }^{\circ} \mathrm{C}\left(20 \mathrm{~s} /{ }^{\circ} \mathrm{C}\right)$. The expression levels relative to the control were estimated by calculating $\Delta \Delta C_{\mathrm{T}}$ and subsequently analyzed using $2^{-\Delta \Delta C_{\mathrm{T}}}$ method (Kim et al., 2013).

\subsection{Western blot analysis}

Anti-inflammatory protein expression was evaluated by Western blot analysis according to standard procedures. The cells were pretreated with GBBAEs and stimulated with LPS for indicated periods at $37{ }^{\circ} \mathrm{C}$. After incubation, the cells were washed with Tris-buffered saline (TBS) twice, then collected and lysed in ice-cold radio-immunoprecipitation assay (RIPA) lysis butter $(50 \mathrm{mmol} / \mathrm{L}$ Tris- $\mathrm{HCl}$ (pH 7.4), $150 \mathrm{mmol} / \mathrm{L} \mathrm{NaCl}, 1 \%$ Nonidet P-40 (NP-40), 0.1\% $(1 \mathrm{~g} / \mathrm{L})$ sodium dodecyl sulfate (SDS), and $100 \mathrm{mmol} / \mathrm{L}$ phenylmethanesulfonyl fluoride (PMSF)), containing a protease inhibitor $50 \times$ cocktail (Roche, Basel, Switzerland) for $30 \mathrm{~min}$ on ice, then centrifuged at $12000 \mathrm{~g}$ for $5 \mathrm{~min}$ to obtain the total protein solution. The protein concentration of extracts was estimated by the Bradford protein assay (Bio-Rad, CA, USA). Also, after quantification of protein concentration, equal amounts of proteins were subjected to SDSpolyacrylamide gel electrophoresis (PAGE) and transferred onto polyvinylidene fluoride (PVDF) membranes. Skim milk (5\%) in TBS with $0.1 \%$ Tween 20 (TBST) was used to block the membranes. Then the membranes were incubated with each specific primary antibody against COX-2 and NF- $\mathrm{KBp} 65$ overnight at $4{ }^{\circ} \mathrm{C}$. The membranes were washed three times for 10 min each between each step and incubated with horseradish peroxidase (HRP)-conjugated 
secondary anti-bodies for $30 \mathrm{~min}$ at room temperature, and then washed again as before. The protein bands were detected by the Amersham ECL system (Amersham-Pharmacia Biotech, Arlington Heights, IL, USA). The relative expression of proteins was quantified using the software Alpha (Alpha Innotech, ProteinSimple, USA) and calculated by the reference bands of $\beta$-actin.

\subsection{Statistical analysis}

Data are expressed as the mean \pm standard deviation (SD) values with at least three replications. The one-way analysis of variance (ANOVA) with treatment as a factor was used to evaluate the significant differences between groups using SPSS Version 18.0 (Esposito et al., 2014). $P<0.05$ was considered to be significant.

\section{Results}

\subsection{Major compounds of GBBAEs}

The major compounds in GBBAEs were explored by HPLC-MS/MS analysis. As presented in Fig. 1 and Table 1, the major compounds were identified by comparison of their mass spectra while the relative contents were calculated by the peak areas. The GBBAEs consist of 11 major compounds. The relative contents of all compounds range from $3 \%$ to $22 \%$. Malvidin-3-galactoside ((19.5656 \pm 0.1746$) \%)$ and malvidin-3-glucoside $((21.5313 \pm 0.0298) \%)$ are the two higher level compounds. The ranges of petunidin-3glucoside, cyanidin-3-glucoside, delphinidin-3-glucoside, delphinidin-3-galactoside, cyanidin-3-galactoside, and petunidin-3-galactoside are almost stable, from $(6.9430 \pm 0.0220) \%$ to $(9.9280 \pm 0.0618) \%$. Malvidin-

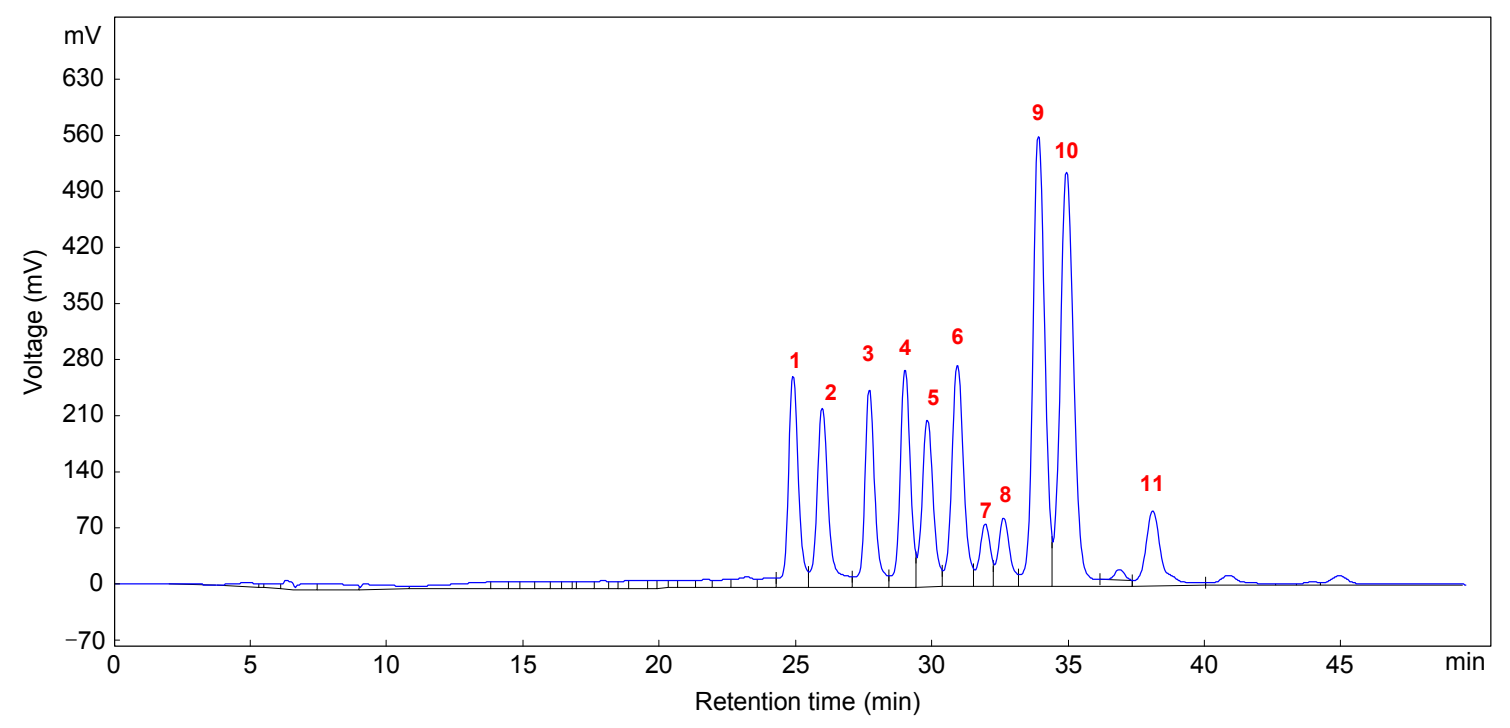

Fig. 1 HPLC analysis of the GBBAEs at $525 \mathrm{~nm}$ Compounds 1-11 are shown in Table 1

Table 1 Identification and analysis of major compounds in GBBAEs by HPLC-ESI-MS/MS detected at $525 \mathrm{~nm}$

\begin{tabular}{cccclc}
\hline Peak & Rt $(\mathrm{min})$ & {$[\mathrm{M}]^{+}(\mathrm{m} / \mathrm{z})$} & MS/MS $(\mathrm{m} / \mathrm{s})$ & \multicolumn{1}{c}{ Identification } & Relative content $(\%)$ \\
\hline 1 & 24.870 & 465 & 303 & Delphinidin-3-galactoside & $7.9711 \pm 0.1313$ \\
2 & 25.939 & 465 & 303 & Delphinidin-3-glucoside & $8.0819 \pm 0.1535$ \\
3 & 27.669 & 449 & 287 & Cyanidin-3-galactoside & $7.4760 \pm 0.0717$ \\
4 & 28.977 & 449 & 287 & Cyanidin-3-glucoside & $8.1975 \pm 0.0607$ \\
5 & 29.798 & 479 & 317 & Petunidin-3-galactoside & $6.9430 \pm 0.0220$ \\
6 & 30.897 & 479 & 317 & Petunidin-3-glucoside & $9.9280 \pm 0.0618$ \\
7 & 31.918 & 419 & 287 & Cyanidin-3-arabinoside & $2.6159 \pm 0.0283$ \\
8 & 32.600 & 463 & 301 & Peonidin-3-galactoside & $3.0492 \pm 0.0437$ \\
9 & 33.671 & 493 & 331 & Malvidin-3-galactoside & $19.5656 \pm 0.1746$ \\
10 & 34.903 & 493 & 331 & Malvidin-3-glucoside & $21.5313 \pm 0.0298$ \\
11 & 38.065 & 463 & 331 & Malvidin-3-arabinoside & $4.6404 \pm 0.4218$ \\
\hline
\end{tabular}

Rt: retention time. Relative content values are expressed as mean $\pm \mathrm{SD}(n=3)$ 
3-arabinoside, peonidin-3-galactoside, and cyanidin3 -arabinoside are three smaller parts. The cyanidin3 -arabinoside content is only $(2.6159 \pm 0.0283) \%$.

\subsection{Effect of GBBAEs on RAW 264.7 cell viability}

We first measured the cytotoxicity of GBBAEs in RAW 264.7 cells using the MTT assay. Fig. 2a shows that GBBAEs-treated groups showed markedly increased absorbance values in the employed concentrations $(400,800$, and $1200 \mu \mathrm{g} / \mathrm{ml})$, when the processing time was $24 \mathrm{~h}$, reaching the maximum levels $(141.78 \%, 147.87 \%$, and $151.79 \% ; P>0.05)$. However, the number of cells in each group was significantly decreased after $48 \mathrm{~h}$. When the processing time was $72 \mathrm{~h}$, the lowest concentration was significantly reduced. This condition may be related to the differentiation and proliferation of GBBAEs in vitro and the short survival time. Therefore, $24 \mathrm{~h}$ was considered to be the optimal inoculation time for the time-dependent analysis.
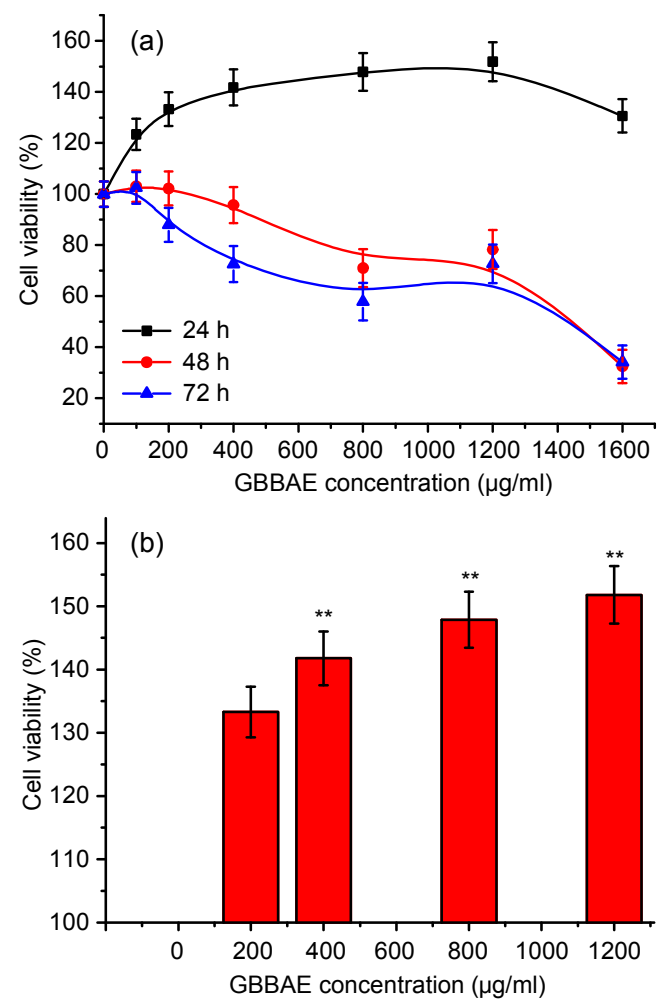

Fig. 2 Effects of GBBAEs on cell viability of murine RAW 264.7 cells

(a) Cells were treated 0, 200, 400, 800, 1200, and $1600 \mu \mathrm{g} / \mathrm{ml}$ GBBAEs for 24,48 , and $72 \mathrm{~h}$, respectively. Cell viability was quantified spectrophotometrically by the MTT assay. (b) Cells were treated 200, 400, 800, and $1200 \mu \mathrm{g} / \mathrm{ml} \mathrm{GBBAEs}$ for $24 \mathrm{~h}$, respectively. The reported values are the mean $\pm \mathrm{SD}(n=6)$. ${ }^{* *} P<0.01$ versus $200 \mu \mathrm{g} / \mathrm{ml}$ GBBAEs
As shown in Fig. 2b after GBBAE administration for $24 \mathrm{~h}$, the cell viability of all groups increased. Comparing the concentrations used, the growth of RAW 264.7 was promoted by GBBAEs in a dosedependent manner. GBBAEs did not influence the cytotoxicity of RAW 264.7 cells at the concentrations used $(400,800$, and $1200 \mu \mathrm{g} / \mathrm{ml})$. Therefore, in all subsequent experiments, we used concentrations of GBBAEs ranging from 400 to $1200 \mu \mathrm{g} / \mathrm{ml}$.

\subsection{Effect of GBBAEs on the NO production}

NO is a signaling molecule involved in a broad spectrum of pathophysiological processes, such as inflammation, apoptosis, regulation of enzyme activity, and gene expression. High NO levels are generated in response to inflammatory stimuli and mediate proinflammatory effects (Korhonen et al., 2005). As shown in Fig. 3, the NO production of LPS-induced RAW 264.7 was markedly increased to $100 \%$ when $1 \mu \mathrm{g} / \mathrm{ml}$ LPS was added, compared with $3.15 \%-5.53 \%$ for untreated control cells. The NO production decreased significantly in a dose- and time-dependent manner. When GBBAE administration was $1200 \mu \mathrm{g} / \mathrm{ml}$ for $24 \mathrm{~h}$, the NO production decreased by $33.11 \%$ $(P<0.05)$, compared with $18.40 \%$ in $12 \mathrm{~h}$ and $19.54 \%$ in $48 \mathrm{~h}$. According to previous studies (Yan et al., 2013), the NO inhibitory effect is similar to the fingered citron. Although the anti-inflammatory effect of blueberry extracts has been explored in animal experiments (Shi et al., 2014), that in NO production of LPS-induced RAW 264.7 has not been reported.

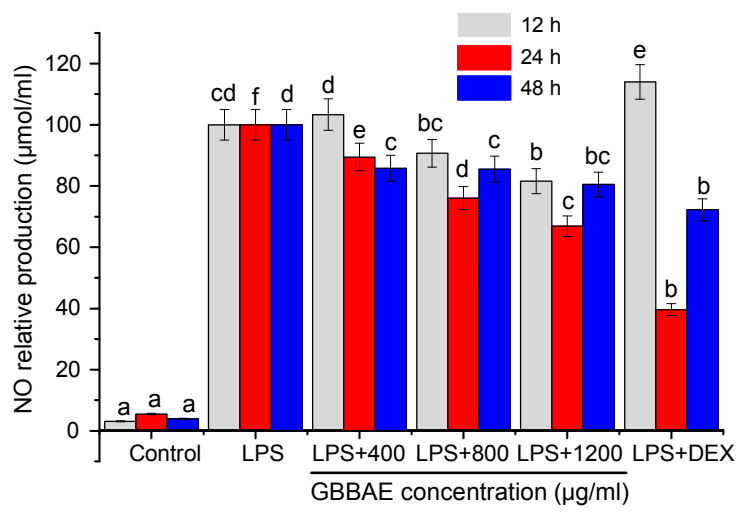

Fig. 3 Effects of GBBAEs on NO production in LPSstimulated murine RAW 264.7 cells

Cells were pretreated with LPS $(1 \mu \mathrm{g} / \mathrm{ml})$ before stimulated with 400,800 , and $1200 \mu \mathrm{g} / \mathrm{ml}$ of GBBAEs in the presence for 12,24 , and $48 \mathrm{~h}$, respectively. As a control, cells were incubated with vehicle alone. The reported values are the mean $\pm \mathrm{SD}$ $(n=3)$. Different letters indicate significant differences $(P<0.05)$. DEX: dexamethasone 


\subsection{Effects of GBBAEs on the secretions of $\mathrm{PGE}_{2}$, INF- $\gamma$, IL-1 $\beta$, and IL-6}

To determine the effects of GBBAEs on the secretions of the proinflammatory cytokines $\mathrm{PGE}_{2}$, INF- $\gamma$, IL-1 $\beta$, and IL-6, RAW 264.7 cells were pretreated with various concentrations of GBBAEs (400, 800 , and $1200 \mu \mathrm{g} / \mathrm{ml}$ ) and stimulated with $1 \mu \mathrm{g} / \mathrm{ml}$ of LPS for $24 \mathrm{~h}$. As shown in Figs. 4a-4d, the levels of $\mathrm{PGE}_{2}$, INF- $\gamma$, IL- $1 \beta$, and IL- 6 were significantly increased in the LPS-treated cells when compared with the untreated cells. However, the levels of $\mathrm{PGE}_{2}$, INF- $\gamma$, IL- $1 \beta$, and IL- 6 were significantly reduced in the cells pretreated with GBBAEs in a dosedependent manner. These results demonstrate that GBBAEs inhibited the production of $\mathrm{PGE}_{2}$, INF- $\gamma$, IL-1 $\beta$, and IL-6 effectively.

\subsection{Effects of GBBAEs on the mRNA expressions of COX-2, MCP-1, IL-6, IL-1 $\beta$, and TNF- $\alpha$}

As shown in Fig. 5, the effects of GBBAEs on LPS-stimulated MCP-1, COX-2, IL-6, IL-1 $\beta$, and $\mathrm{TNF}-\alpha$ protein expressions in RAW 264.7 cells were
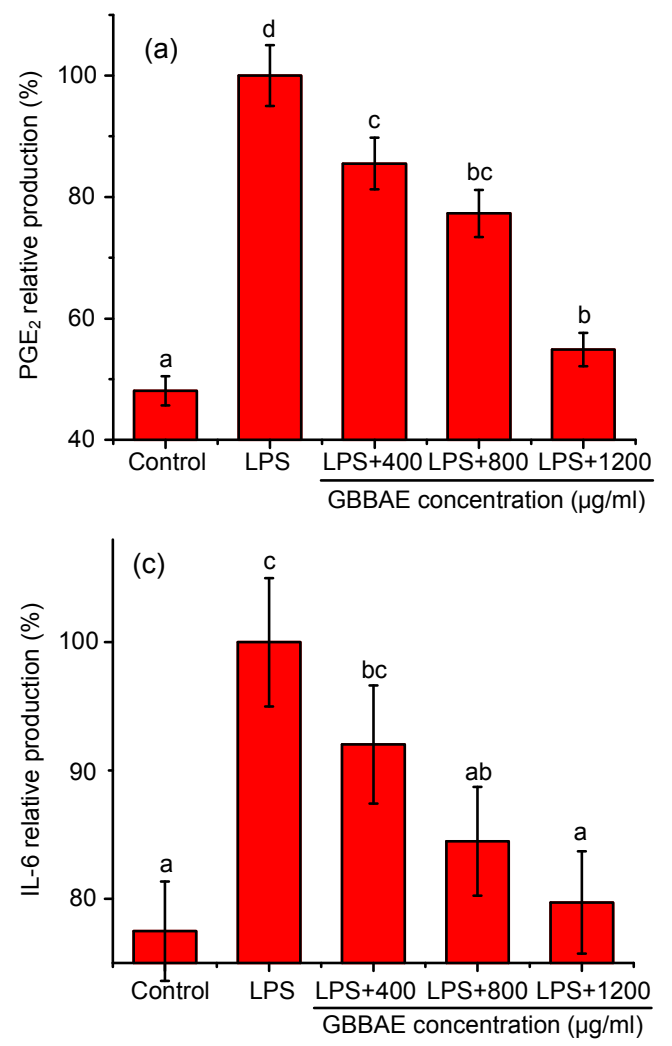

examined by RT-PCR. Figs. $5 \mathrm{a}$ and $5 \mathrm{~b}$ show the gene expression levels of COX-2 and MCP-1, the only cells chosen as the control (mRNA fold production is 1). The two gene expression levels of RAW 264.7 were significantly inhibited by GBBAEs in a dosedependent manner $(P<0.05)$ especially $1200 \mu \mathrm{g} / \mathrm{ml}$. As for IL- $1 \beta$ and IL-6 shown in Figs. $5 \mathrm{c}$ and $5 \mathrm{~d}$, the lower GBBAE concentrations showed significant differences $(P<0.05)$ in IL-6 gene expression levels but no effect in IL-1 $\beta \quad(P>0.05)$. With the increase of GBBAE concentration, the two gene expression levels were completely inhibited in $1200 \mu \mathrm{g} / \mathrm{ml}$, which indicated that a suitable concentration of GBBAEs can completely inhibit IL- $1 \mathrm{~b}$ and IL-6 secreted from RAW 264.7 cells. Although there were no effects $(P>0.05)$ on TNF- $\alpha$ gene expression in Fig. 5e, there was a tendency toward the TNF- $\alpha$ level decline by the increase of GBBAE concentration.

\subsection{Effects of GBBAEs on the relative protein expressions of COX-2 and NF-KBp65}

The relative protein expressions are shown in Fig. 5f. LPS at $1 \mu \mathrm{g} / \mathrm{ml}$ induced a significant increase
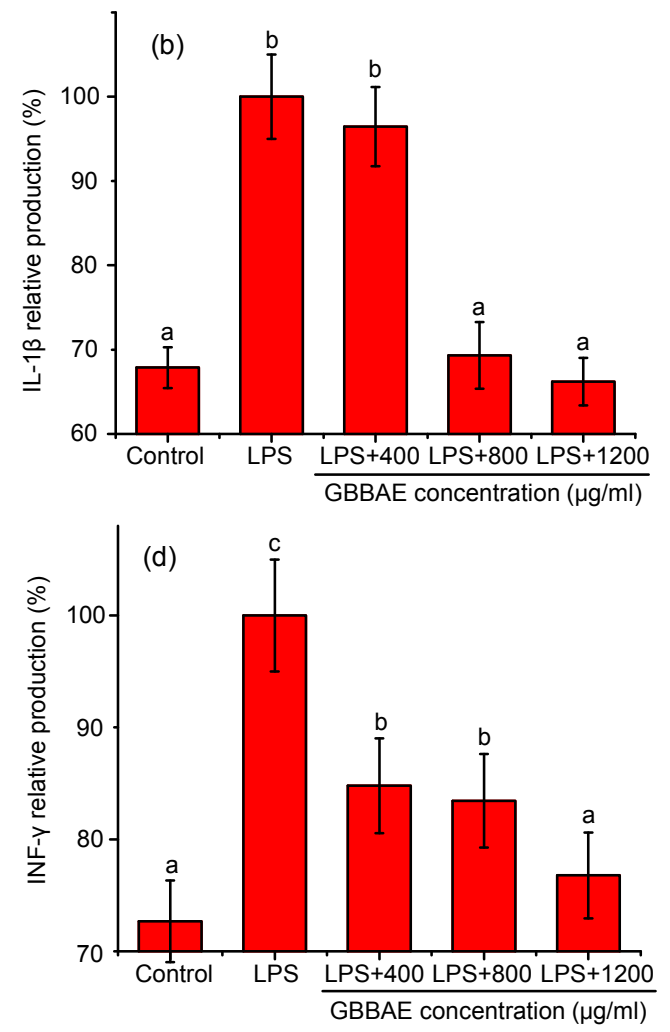

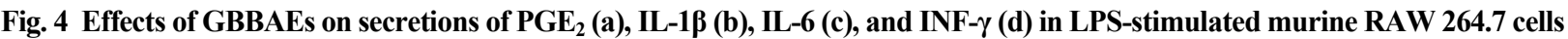
Cells were pretreated with LPS $(1 \mu \mathrm{g} / \mathrm{ml})$ before stimulated with 400,800 , and $1200 \mu \mathrm{g} / \mathrm{ml}$ of GBBAEs in the presence for $24 \mathrm{~h}$, respectively. As a control, cells were incubated with vehicle alone. The reported values are the mean $\pm \mathrm{SD}(n=3)$. Different letters indicate significant differences $(P<0.05)$ 
in COX-2 protein expression, compared with the control. In the range of 400,800 , and $1200 \mu \mathrm{g} / \mathrm{ml}$, pretreatment with GBBAEs resulted in the inhibition of this LPS-induced COX-2 protein expression in a dosedependent manner. Although the inhibitory effect was not significant at a low concentration, a significant
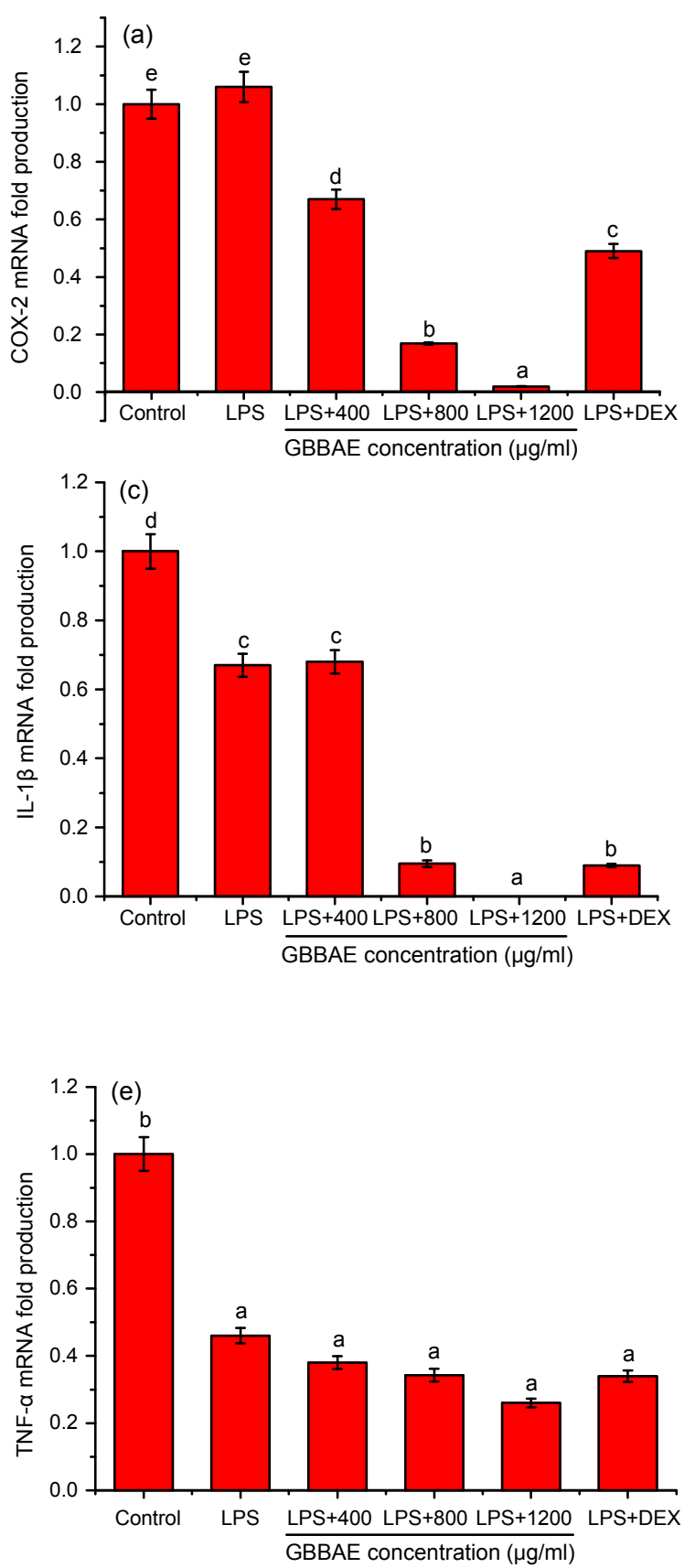

effect appeared when the concentration reached $1200 \mu \mathrm{g} / \mathrm{ml}$. The inhibitory ratio ranged from $15.04 \%$ to $46.90 \%$, the latter of which is close to that of the positive group $(45.13 \%)$. This finding is in accordance with the mRNA expression of COX-2 in Fig. 5a.
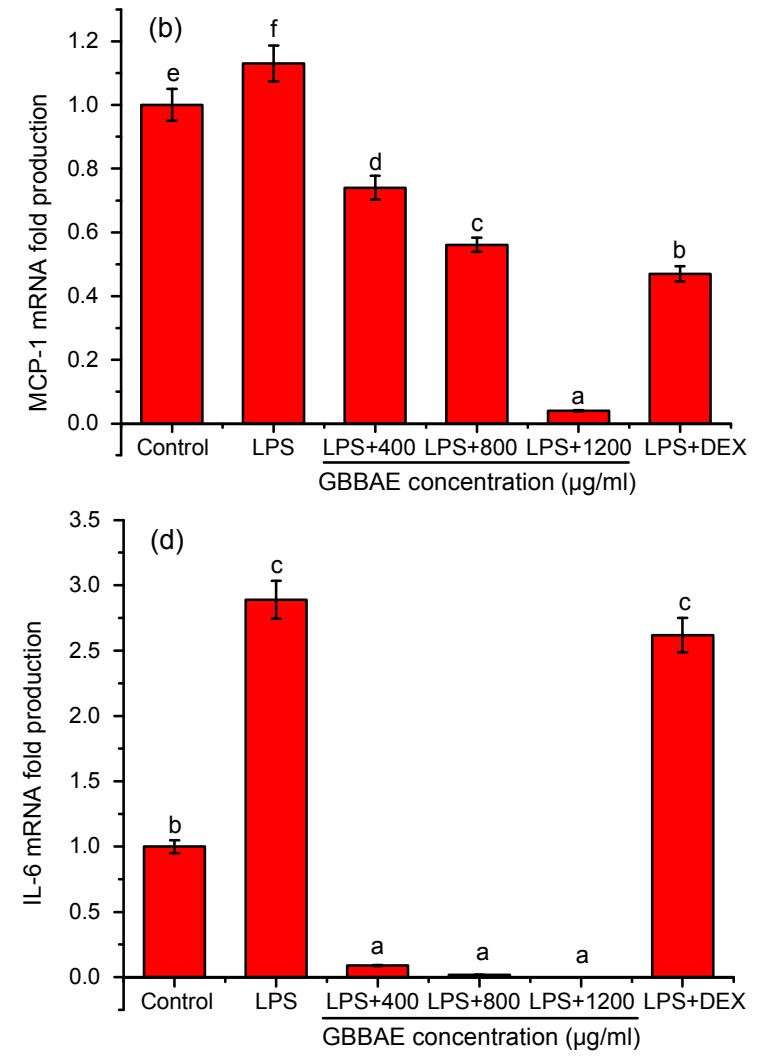

(f)

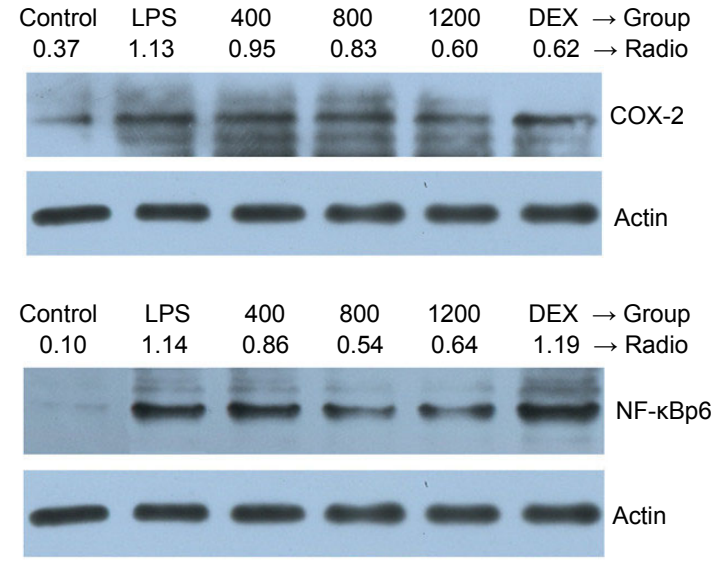

Fig. 5 Effects of GBBAEs on mRNA expression levels of COX-2 (a), MCP-1 (b), IL-1ß (c), IL-6 (d), and TNF- $\alpha$ (f) and on the protein expressions of COX-2 (f) and NF-кBp65 (g) in LPS-stimulated murine RAW 264.7 cells

Cells were pretreated with LPS $(1 \mu \mathrm{g} / \mathrm{ml})$ before stimulated with 400,800 , and $1200 \mu \mathrm{g} / \mathrm{ml}$ of GBBAEs in the presence for $24 \mathrm{~h}$, respectively. As a control, cells were incubated with vehicle alone. The reported values are the mean $\pm \operatorname{SD}(n=3)$. Different letters indicate significant differences $(P<0.05)$. DEX: dexamethasone 
As is known, NF- $\kappa \mathrm{B}$ subunits are retained in the cytoplasm by binding to the inhibitory $\mathrm{I} \kappa \mathrm{B}$ protein in unstimulated cells. Upon stimulation, dephosphorylation and subsequent degradation of $\mathrm{I} \kappa \mathrm{B}$ liberates NF- $\kappa \mathrm{B}$ subunit p65 to enter the nucleus and bind to DNA target sites (Wang T.Y. et al., 2014). We examined the phosphorylation of $\mathrm{p} 65$ by Western blot analysis because of the primary subunit of NF- $\kappa B$ activated by LPS in macrophages. Western blot was also used to examine whether GBBAEs affect the binding of NF- $\kappa \mathrm{B}$. As presented in Fig. $5 \mathrm{~g}$, in the range of 400,800 , and $1200 \mu \mathrm{g} / \mathrm{ml}$, pretreatment with GBBAEs resulted in the inhibition of this LPS-induced NF-кBp65 protein expression in a concentrationdependent manner. The inhibitory ratio ranged from $24.56 \%$ to $43.86 \%$, but the positive group showed no significant inhibition. In summary, the results indicate that the GBBAEs suppress inflammatory response via the NF- $\kappa$ B pathway. The flowsheet of the antiinflammatory effect of GBBAEs through NF- $\kappa \mathrm{B}$ is presented in Fig. 6.

\section{Discussion}

Anthocyanins with different aglycones and sugar moieties have different bioavailability and potential health effects (Wu et al., 2006). This study not only showed some similar effects to the former studies but also differences. Although the LPS-induced model to study the anti-inflammatory activity in BV2 microglial cells was explored by Lau et al. (2007), the model in RAW 264.7 cells has not yet been explored. The present study indicates that the RAW 264.7 cells can be successfully set up to be a platform of virus-induced inflammation as an in vitro model.

In terms of the compounds of the GBBAEs, Yousef et al. (2013) showed the richest species of 18 anthocyanins in blueberry. In the reported 18 species, the content of delphenidin 3-O-(6"-acetyl) glucoside, cyanidin 3-O-(6"-acetyl) glucoside, malvidin 3-O(6"-acetyl), petunidin 3-O-(6"-acetyl) glucoside, and malvidin 3-O-(6"-acetyl) glucoside, which do not exist in our study, is only $4.6 \%$. Compared with previous study (Yousef et al., 2013), our study found only 11 species which constitute the majority of the anthocyanins. Thus the abundance of other species is in accordance with most studies (Cheng et al., 2014). There are not many differences in the varieties of anthocyanins but there were in the relative content of anthocyanin compounds of different resources. Based on the differences of instruments and methods, the results obtained were in the range of allowable error.

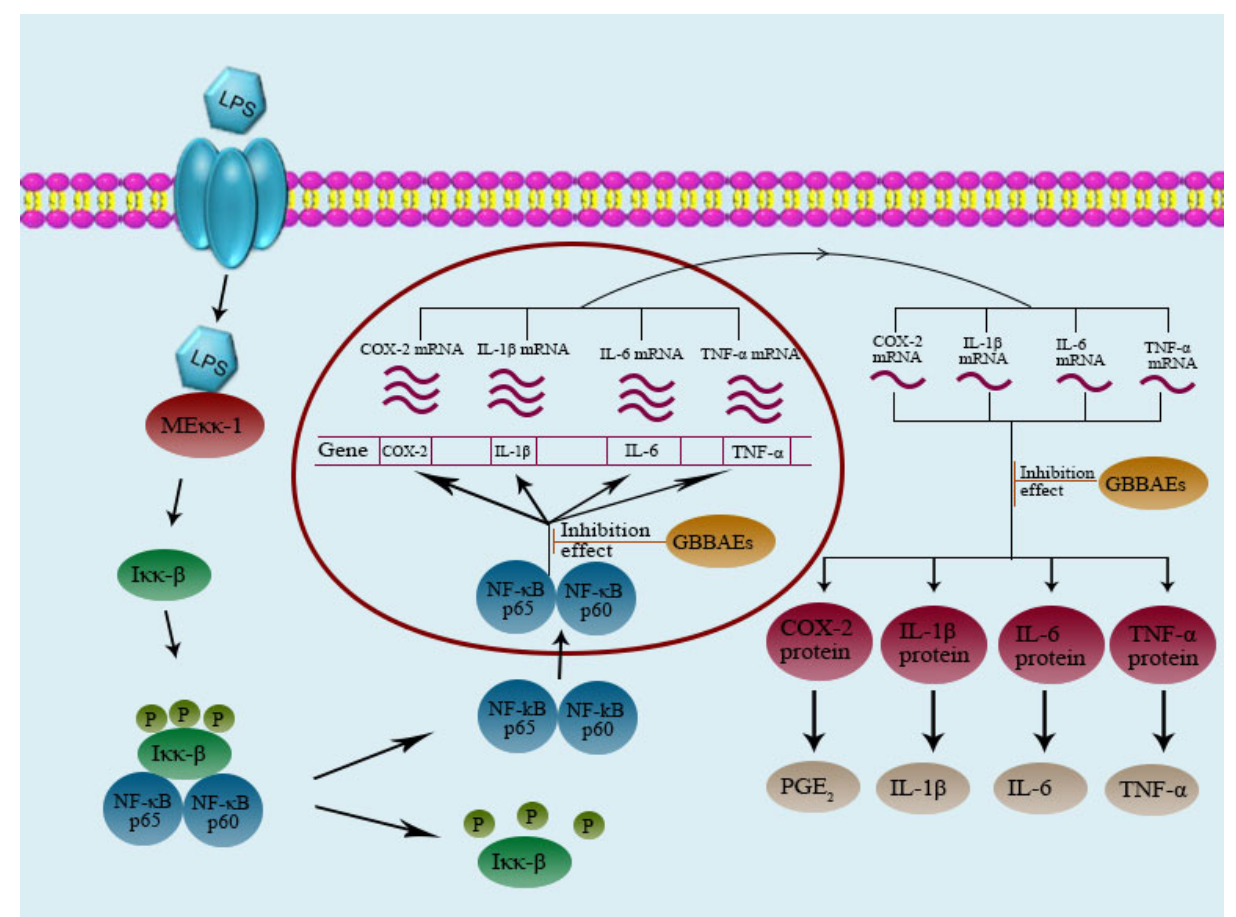

Fig. 6 Schematic diagram about the pathway of GBBAEs in LPS-stimulated murine RAW 264.7 cells 
As to the NO inhibitory effect, multiple studies suggest that elevated NO production and oxidative stress in activated macrophages are closely related to inflammation, the development of atherosclerosis and cancer (Berliner et al., 1995; Iqbal et al., 2002; Lee et al., 2003). Excessive proinflammatory cytokine and $\mathrm{NO}$ production through $\mathrm{NF}-\mathrm{\kappa B}$ activation play an important role in inflammatory diseases (Southan and Szabo, 1996). The underlying mechanisms of blueberry anthocyanins have not been completely studied. In this study, the GBBAEs show a similar effect to many polysaccharides, which are widely used to prevent the inflammatory diseases. It appears that GBBAEs have the potential to be an immunopotentiator.

As to the secretions of relative cytokines, various studies concentrated on different cytokines. We chose the typical cytokines such as $\mathrm{PGE}_{2}, \mathrm{INF}-\gamma$, IL- $1 \beta$, and IL-6 for analysis. IL-1 is well-known to be a proinflammatory cytokine which is constitutively secreted and activated. It mediates macrophage chemotaxis, angiogenesis, and sustained melanoma growth. IL-1 $\beta$ is the neutral isoform of IL-1 and plays a significant role in tumor development and progression (Okamoto et al., 2010). IL-6 is a multifunctional cytokine that controls many biological processes such as inflammation, differentiation of immune cells, and hepatic regeneration in response to diverse stimuli (Heinrich et al., 2003). Mann et al. (2005) reported that $\mathrm{PGE}_{2}$ secretion associated with $\mathrm{COX}-2$ can promote tumor growth and metastasis. Comparing with previous studies in various plant extracts, GBBAEs showed similarly significant inhibition effects on IL-6 and $\mathrm{PGE}_{2}$ especially in polyphenol composition. Although the inhibition tendencies of INF- $\gamma$ and IL- $1 \beta$ are the same, the effect presented showed little difference.

The relative mRNA and protein expressions were evaluated further. When the same dose of GBBAEs was used on LPS-induced RAW 264.7 cells, the results demonstrated greater suppressive effects on the relative mRNA expressions of COX-2, MCP-1, and IL- 6 release than on that of TNF- $\alpha$ and IL-1 $\beta$, which implies that GBBAEs showed selective inhibitory effects on COX-2, MCP-1, and IL-6 production. Comparing the differences with the study of Lau et al. (2007), all those results further confirmed the activity in various species of anthocyanins. In particular, the protein expression showed that the inhibitory effects of GBBAEs on COX-2 and NF- $\kappa B p 65$ were owing to the attenuation of NF- $\kappa B$ nuclear translocation. Upon activation, NF- $\mathrm{KB}$ translocates into the nucleus to initiate the expression of over 200 immune, growth, and inflammation genes (Aggarwal, 2004). Thus the cell-signaling properties in this study may be independent of their traditional antioxidant activities. The anti-inflammatory activity contributes to the results.

Given the complexity of the inflammatory reaction, the precise mechanism underlying the neuroprotective properties of GBBAEs is unclear. Based on our results, it is important first to prove the antiinflammatory effects by building the LPS-induced RAW 264.7 model in vitro. In the future, we plan to investigate further the possible role and biomedical significance of GBBAEs in NF- $\mathrm{kB}$ activation as well as other stress signaling cascades.

\section{Conclusions}

In conclusion, we isolated 11 kinds of anthocyanins in the GBBAEs, of which the major compounds are malvidin-3-glucoside and malvidin-3-galactoside. By successfully establishing an LPS-induced inflammatory RAW 264.7 model in vitro, the study shows that GBBAEs significantly inhibited the release of typical cytokines, the levels of relative inflammatory mRNA and protein expressions. Furthermore, the preliminary results further elucidated the molecular mechanisms governing the antiinflammatory properties through the NF- $\mathrm{kB}$ pathways, indicating the protection of inflammatory cells. This is in accordance with the function groups of anthocyanins in former studies. We suggest that GBBAEs may present a powerful means for the development of anti-inflammatory nutraceuticals to human benefit.

\section{Acknowledgements}

We thank the Hubei Cowherd Blueberry Technology Co., Ltd. (Wuhan City, Hubei Province, China) for providing Gardenblue blueberry (Vaccinium ashei Reade).

\section{Compliance with ethics guidelines}

Wei XU, Qing ZHOU, Yong YAO, Xing LI, Jiu-liang ZHANG, Guan-hua SU, and Ai-ping DENG declare that they have no conflict of interest.

This article does not contain any studies with human or animal subjects performed by any of the authors. 


\section{References}

Aggarwal, B.B., 2004. Nuclear factor-кB: the enemy within. Cancer Cell, 6(3):203-208. http://dx.doi.org/10.1016/j.ccr.2004.09.003

Almeida, J., D'Amico, E., Preuss, A., et al., 2007. Characterization of major enzymes and genes involved in flavonoid and proanthocyanidin biosynthesis during fruit development in strawberry (Fragaria $\times$ ananassa). Arch. Biochem., 465(1):61-71. http://dx.doi.org/10.1016/j.abb.2007.04.040

Berliner, J.A., Navab, M., Fogelman, A.M., et al., 1995. Atherosclerosis: basic mechanisms: oxidation, inflammation and genetics. Circulation, 91(9):2488-2496. http://dx.doi.org/10.1161/01.CIR.91.9.2488

Cheng, A.W., Yan, H.Q., Han, C.J., et al., 2014. Polyphenols from blueberries modulate inflammation cytokines in LPS-induced RAW 264.7 macrophages. Int. J. Biol. Macromol., 69:382-387. http://dx.doi.org/10.1016/j.ijbiomac.2014.05.071

Dobrovolskaia, M.A., Vogel, S.N., 2002. Toll receptors, CD14, and macrophage activation and deactivation by LPS. Microbes Infect., 4(9):903-914. http://dx.doi.org/10.1016/S1286-4579(02)01613-1

Esposito, D., Chen, A., Grace, M.H., et al., 2014. Inhibitory effects of wild blueberry anthocyanins and other flavonoids on biomarkers of acute and chronic inflammation in vitro. J. Agric. Food Chem., 62(29):7022-7028. http://dx.doi.org/10.1021/jf4051599

Heinrich, P.C., Behrmann, I., Haan, S., et al., 2003. Principles of interleukin (IL)-6-type cytokine signalling and its regulation. Biochem. J., 374(1):1-20. http://dx.doi.org/10.1042/bj20030407

Hsu, C.L., Fang, S.C., Liu, C.W., et al., 2013. Inhibitory effects of new varieties of bitter melon on lipopolysaccharidestimulated inflammatory response in RAW 264.7 cells. $J$. Funct. Foods, 5(4):1829-1837. http://dx.doi.org/10.1016/j.jff.2013.09.002

Iqbal, M., Cohen, R.I., Marzouk, K., et al., 2002. Time course of nitric oxide, peroxynitrite and antioxidants in the endotoxemic heart. Crit. Care Med., 30(6):1291-1296. http://dx.doi.org/10.1097/00003246-200206000-00021

Johnson, M.H., Mejia, E.G., Fan, J., et al., 2013. Anthocyanins and proanthocyanidins from blueberry-blackberry fermented beverages inhibit markers of inflammation in macrophages and carbohydrate-utilizing enzymes in vitro. Mol. Nutr. Food Res., 57(7):1182-1197. http://dx.doi.org/10.1002/mnfr.201200678

Kim, K.N., Heo, S.J., Yoon, W.J., et al., 2010. Fucoxanthin inhibits the inflammatory response by suppressing the activation of NF- $\mathrm{KB}$ and MAPKs in lipopolysaccharideinduced RAW 264.7 macrophages. Eur. J. Pharmacol., 649(1-3):369-375. http://dx.doi.org/10.1016/j.ejphar.2010.09.032

Kim, K.N., Ko, Y.J., Yang, H.M., et al., 2013. Antiinflammatory effect of essential oil and its constituents from fingered citron (Citrus medica L. var. sarcodactylis) through blocking JNK, ERK and NF- $\mathrm{BB}$ signaling pathways in LPS-activated RAW 264.7 cells. Food Chem. Toxicol., 57:126-131. http://dx.doi.org/10.1016/j.fct.2013.03.017

Korhonen, R., Lahti, A., Kankaanranta, H., et al., 2005. Nitric oxide production and signaling in inflammation. Curr. Drug Target Inflamm. Allergy, 4(4):471-479. http://dx.doi.org/10.2174/1568010054526359

Lau, F.C., Bielinski, D.F., Joseph, J.A., 2007. Inhibitory effects of blueberry extract on the production of inflammatory mediators in lipopolysaccharide-activated BV2 microglia. J. Neurosci. Res., 85(5):1010-1017. http://dx.doi.org/10.1002/jnr.21205

Lee, A.K., Sung, S.H., Kim, Y.C., et al., 2003. Inhibition of lipopolysaccharide-inducible nitric oxide synthase, TNF- $\alpha$ and COX-2 expression by suchinone effects on $\mathrm{I}-\kappa \mathrm{B} \alpha$ phosphorylation, C/EBP and AP-1 activation. Br. J. Phamacol., 139(1):11-20.

http://dx.doi.org/10.1038/sj.bjp.0705231

Li, C.Y., Feng, J., Huang, W.Y., et al., 2013. Composition of polyphenols and antioxidant activity of rabbiteye blueberry (Vaccinium ashei) in Nanjing. J. Agric. Food Chem., 61(3):523-531. http://dx.doi.org/10.1021/jf3046158

Lopes, G., Sousa, C., Silva, L.R., et al., 2012. Can phlorotannins purified extracts constitute a novel pharmacological alternative for microbial infections with associated inflammatory conditions? PLOS ONE, 7(2):e31145. http://dx.doi.org/10.1371/journal.pone.0031145

Mann, J.R., Backlund, M.G., DuBois, R.N., 2005. Mechanisms of disease: inflammatory mediators and cancer prevention. Nat. Clin. Pract. Oncol., 2(4):202-210. http://dx.doi.org/10.1038/ncponc0140

Okamoto, M., Liu, W., Luo, Y., et al., 2010. Constitutively active inflammasome in human melanoma cells mediating autoinflammation via caspase-1 processing and secretion of interleukin-1ß. J. Biol. Chem., 285(9):64776488 . http://dx.doi.org/10.1074/jbc.M109.064907

Prior, R.L., Cao, G., Martin, A., et al., 1998. Antioxidant capacity as influenced by total phenolic and anthocyanin content, maturity and variety of Vaccinium species. $J$. Agric. Food Chem., 46(7):2686-2693. http://dx.doi.org/10.1021/jf980145d

Shi, L., Liu, Y.E., Tan, D.H., et al., 2014. Blueberry anthocyanins ameliorate cyclophosphamide-induced liver damage in rats by reducing inflammation and apoptosis. $J$. Funct. Foods, 11:71-81. http://dx.doi.org/10.1016/j.jff.2014.07.008

Southan, G.J., Szabo, C., 1996. Selective pharmacological inhibition of distinct nitric oxide synthase isoforms. Biochem. Pharmacol., 51(4):383-394. http://dx.doi.org/10.1016/0006-2952(95)02099-3

Sun, L., Ding, X., Qi, J., et al., 2012. Antioxidant anthocyanins 
screening through spectrum-effect relationships and DPPH-HPLC-DAD analysis on nine cultivars of introduced rabbiteye blueberry in China. Food Chem., 132(2): 759-765.

http://dx.doi.org/10.1016/j.foodchem.2011.11.030

Wang, L., Nie, Z.K., Zhou, Q., et al., 2014. Antitumor efficacy in $\mathrm{H} 22$ tumor bearing mice and immunoregulatory activity on RAW 264.7 macrophages of polysaccharides from Talinum triangulare. Food Funct., 5(9):1979-1980. http://dx.doi.org/10.1039/C4FO90026J

Wang, T.Y., Wu, F.H., Jin, Z.G., et al., 2014. Plumbagin inhibits LPS-induced inflammation through the inactivation of the nuclear factor-kappa B and mitogen activated protein kinase signaling pathways in RAW 264.7 cells. Food Chem. Toxicol., 64:177-183. http://dx.doi.org/10.1016/j.fct.2013.11.027

Wu, X., Beecher, G.R., Holden, J.M., et al., 2006. Concentrations of anthocyanins in common foods in the United States and estimation of normal consumption. J. Agric. Food Chem., 54(11):4069-4075. http://dx.doi.org/10.1021/jf0603001

Yan, H.Q., Ma, Z.C., Peng, S.A., et al., 2013. Antiinflammatory effect of auraptene extracted from trifoliate orange (Poncirus trifoliate) on LPS-stimulated RAW 264.7 cells. Inflammation, 36(6):1525-1532. http://dx.doi.org/10.1007/s10753-013-9695-y

Yousef, G.G., Brown, A.F., Funakoshi, Y., et al., 2013. Efficient quantification of the health-relevant anthocyanin and phenolic acid profiles in commercial cultivars and breeding selections of blueberries (Vaccinium spp.). $J$. Agric. Food Chem., 61(20):4806-4815. http://dx.doi.org/10.1021/jf400823s

Zhang, Z.C., Su, G.H., Luo, C.L., et al., 2015. Effects of anthocyanins from purple sweet potato (Ipomoea batatas L. cultivar Eshu No. 8) on the serum uric acid level and xanthine oxidase activity in hyperuricemic mice. Food Funct., 6(9):3045-3055. http://dx.doi.org/10.1039/C5FO00499C

\section{中文概要}

题 目: 蓝莓花青素对 RAW 264.7 细胞的抗炎活性研究 及其机理初探

目 的: 以园蓝为研究材料, 鉴定园蓝花青素提取物 (GBBAEs) 中的功能性成分的结构, 建立脂多 糖（LPS）诱导的体外炎症模型, 并评价其抗炎 作用和初步机制。

创新点: 首次探究了蓝莓花青素对建立的 LPS 诱导体外炎 症模型的营养干预作用, 并初步探究了发挥抗炎 机制的作用通路。

方 法: 将 RAW 264.7 细胞分为对照组 (不作处理) 和实 验组 $(1 \mu \mathrm{g} / \mathrm{ml}$ LPS 刺激建模)。实验组进一步 分为 3 个不同浓度组: $400 \mu \mathrm{g} / \mathrm{ml}$ GBBAEs 组、 $800 \mu \mathrm{g} / \mathrm{ml}$ GBBAEs 组和 $1200 \mu \mathrm{g} / \mathrm{ml}$ GBBAEs 组。 用酶联免疫吸附测定 (ELISA) 试剂盒检测一氧 化氮 $(\mathrm{NO})$ 、前列腺素 $\mathrm{E}_{2}\left(\mathrm{PGE}_{2}\right)$ 、白细胞介

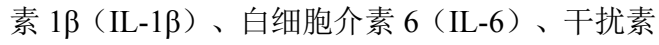
$\gamma$ (INF- $\gamma$ ) 等炎症因子的释放量; 用实时定量聚 合酶链反应 (RT-PCR) 分析 IL-1 $\beta$ 、IL-6、TNF- $\alpha$ 、 环氧合酶-2(COX-2) 及单核细胞趋化蛋白-1 （MCP-1）的炎症相关基因 mRNA 的表达水平; 用蛋白质印迹法 (Western blot 法) 测定相关炎 症蛋白 COX-2 和 NF-kBp65 表达水平。

结 论: 试验结果表明, 通过 ELISA 法测定 GBBAEs 可 以显著性抑制 NO、PGE $2 、$ IL-1 $\beta$ 、IL-6、INF- $\gamma$ 等炎症因子的释放; RT-PCR 分析阐明在 LPS 诱 导的单核-巨筮细胞 RAW 264.7 中, GBBAEs 可 以显著性抑制 IL-1 $\beta$ 、IL-6、TNF- $\alpha 、$ COX-2 及 MCP-1 的炎症相关基因 mRNA 的表达水平。此 外, Western blot 法进一步显示 GBBAEs 对相关 炎症蛋白 COX-2 和 NF- $\mathrm{kBp} 65$ 表达具有明显抑制 作用, 进一步证实 GBBAEs 通过 NF-kB 机制通 路来发挥抗炎作用。

关键词: 园蓝花青素; 抗炎; 单核一巨些细胞 RAW 264.7 细胞; 环氧合酶-2 (COX-2)； NF-kBp65 